vol.4 No.1 - 2017

\title{
SELF ESTEEM, EMOTIONAL INTELLIGENCE AND CONFLICT MANAGEMENT PRACTICE OF ACADEMIC STAFF, FACULTY OF NURSING, MANSOURA UNIVERSITY. Wessam Ahmed Elsayed ${ }^{1 *}$ Reda shehata Elsayed ${ }^{2 *}$ Warda Elshahat Hamed $^{3 *}$ \\ 1,2 (Lecturer in Nursing Administration Department, Faculty of Nursing, Mansoura University, Egypt) \\ 3 (lecturer in Psychiatric Nursing and Mental health department, faculty of nursing, Mansoura university, Egypt). \\ Co-responder author : hamed.waeda@yahoo.com
}

Abstract

Background: Experiences in a personnel life are the most important source of self-esteem, emotional intelligence and conflict management development. The positive or negative life experiences one has, creates attitudes toward the self which can be constructive or can be unfavorable which in turn reflects on levels of self esteem, emotional intelligence and also conflict management. Aim: Study aimed to assess level of self esteem, emotional intelligence and conflict management of academic staff, faculty of Nursing, Mansoura university. Methods: Descriptive co relational design .Sample included all academic staff at faculty of Nursing, Mansoura university. Total number of academic staff were 118. There are three tools used in data collection. Self esteem questionnaire, Emotional intelligence questionnaire and Conflict management questionnaire Results: The most of the studied sample had moderately self esteem $(70.3 \%)$ while the least had high self esteem $(6.8 \%)$, $(84.7 \%)$ of them had highly level of emotional intelligence and also, $(76.3 \%)$ had a highly level of conflict management Conclusion: There was no significant relationship between academic staff level of self esteem and conflict management but, there was a significant positive correlation between total scores of both emotional intelligence and conflict management Recommendation: Encourage open discussion and effective communication between academic staff and administrative authority so that all academic staff get the right information at the right time to manage misunderstanding and conflict.

Keywords: Self esteem, Emotional intelligence, conflict management practice and academic staff.

\section{Introduction:}

Experiences in a personnel life are the most important source of self-esteem development. The positive or negative life experiences one has, creates attitudes toward the self which can be constructive and develop positive feelings of selfworth, or can be un favorable and develop negative feelings of self-worth and also develop personal emotional intelligence which in turn reflects on personal conflict management(1).

Self-esteem is "A judgment of oneself as well as an attitude toward the self". It also "reflects person's overall emotional evaluation of his or her own worth. Selfesteem could be positive or negative feeling about self. Self-esteem is also known as the evaluative dimension of the self that includes feelings of worthiness, prides and discouragement (2) Most authorities believe that self esteem is a central factor and a base to people social and emotional compatibility (3) so; people with a high level of self-esteem have certain characteristics as firmly believe in certain values and principles. They do not lose time worrying excessively about what happened in the past, nor about what could happen in the future, they learn from the past and plan for the future, but live in the present intensely, fully trust in their capacity to solve problems, not hesitating after failures and difficulties. They ask others for help when they need it (4).

On the other hand, persons with low self-esteem may show some of the 
following characteristics, heavy selfcriticism and dissatisfaction, hypersensitivity to criticism with resentment against critics and feelings of being attacked, chronic indecision and an exaggerated fear of mistakes (5). Which in turn reflects on their emotional compatibility and their ability to face conflict (6). Emotional intelligence is a topic that attempts to clarify and interprets feeling, excitement and capability status (7). It is a set of non cognitive skills, abilities, and capacities that make the persons resistant to external demands and pressures (8). Emotional intelligence is the -awareness and sensitivity to the feelings of self and others. Understanding personal emotions specially leads to psychological adjustment and ability to control negative affect and low self esteem" (9).

Emotional intelligence is not a single trail or ability rather, a composite of distinct emotion reasoning abilities. Therefore, perceiving emotions consists of recognizing and interpreting the meaning of various emotional states, as well as their relation to other sensory experiences. Understanding emotions involves comprehensions of how basic emotions are blended to form complex emotions. Regulating emotions encompasses the control of emotions in oneself and others(10).

The talent of using emotions to facilitate problem solving or generating excitement in the performance group plays an important role. Progression of positive emotions within the group, facilitates collaboration and group participation and reduces conflict and also improves the efficiency of group members (11).

Competition, differences and interpersonal roles between individuals are some of the sources of conflict in the organization, the employees who have a healthy level of self esteem and emotional intelligence can deal effectively with conflict in the organization. Through not feeling guilty when others don't like their choice, do not lose time worrying excessively about what happened in the past, nor about what could happen in the future (12).

The human relations view of conflict management dominated from the late 1940s through the mid-1970s. This viewpoint argued that conflict was a natural and inevitable occurrence in any organizational setting. Because conflict was considered unavoidable, the human relations approach recommended acceptance of conflict. In other words, conflict cannot be eliminated and may even benefit the organization. It was during this time period that the term "conflict management "was introduced,(13).

Conflict refers to perceived incompatibilities resulting typically from some form of interference or opposition. It can be defined as a state of discord or clash caused by the actual or perceived opposition of needs, values and interests between people working together. (13).

Conflict management then, is the employment of strategies to correct these perceived differences in a positive manner. For many decades, managers had been taught to view conflict as a negative force. However, conflict may actually be either functional or dysfunctional. Whereas dysfunctional conflict is destructive and leads to decreased productivity, functional conflict may actually encourage greater work effort and help task performance(14). Self esteem is considered a main factor in developing individual emotional intelligence which considered as predictors of success because they reflect how individuals apply knowledge to immediate situation. Which, recognized as an influential factor in individual practice of conflict management that might be an essential factor to improve academic staff practices and faculty outcomes (15) 
Aim of study:

1-Assess levels of self esteem among academic staff at faculty of Nursing Mansoura University.

2-Assess levels of emotional intelligence among academic staff at faculty of Nursing - Mansoura University.

3- Determine conflict management practice levels among academic staff at faculty of Nursing - Mansoura University.

4- Examine the relation between levels of self esteem, emotional intelligence and conflict management among academic staff at faculty of Nursing - Mansoura University.

Research Questions:

1- What are the levels of self esteem among academic staff at faculty of Nursing -Mansoura University?

2- What are the levels of academic staff emotional intelligence at faculty of Nursing- Mansoura University?

3- What are the levels of conflict management practice among academic staff at faculty of NursingMansoura University?

4- Is there a relation between levels of self esteem, emotional intelligence and conflict management practice among academic staff at faculty of NursingMansoura University?

Subject and method :

Desgin:- Descriptive co relational design

Setting: Faculty of Nursing, Mansoura

University.

Subjects:-

The study sample included all nurse educators (assistant professors, lecturers, assistant lecturers, and demonstrators) available at the time of the study in the faculty of nursing_ Mansoura university

.Their total numbers were 118 nurse educators.

Tools of data collection:-

Three tools were used to collect the data of this study

\section{a- The first tool:}

Self esteem questionnaire (16), 17it contains two parts: The 1st part contains Demographic characteristics of the studied sample (as department, marital status, age, job degree and years of experience) .The 2nd part aims to determine the opportunity for improving self esteem. It contains 22 statements and should be answered by yes or no the more yes answers participant has the greater the opportunity for improving self esteem.

\section{b-The second tool:}

Emotional Intelligence questionnaire. It is developed by (17) and aims to measure Emotional intelligence of academic staff. It contains 37 items divided into 5 major items namely, self conscious (8 items), self regulation (8 items), Motivation (8 items), Empathy (6 items) and Social skills (7 items).

\section{c-The third Tool is Conflict} management questionnaire: This tool aims to identify the level of conflict resolution. It contains 25 statement and the answer ranged from definitely true (do) to definitely not true (don't).

Validity and reliability:

The reliability and validity of the study tools are well established. For the purpose of this study, the tools translated into Arabic language. Five faculty members verified the face and content validity of the translated versions of the instruments. A pilot study with 20 academic staff was conducted to ensure internal consistency reliability of the translated versions of the self esteem, emotional intelligence and conflict management. The result was 0.97 for questionnaire.

Pilot study: A pilot study was carried out on a $10 \%$ of the total sample was drawn from each Faculty department to test the instruments and the feasibility of the study. The pilot study done to test the instruments for any inaccuracies. Moreover to identify any details that need 
to be addressed before the main data collection goes ahead and enable the researcher to refine the instrument and be assured of the feasibility of the study.

\section{Statistical analysis:}

The collected data were organized, tabulated and statistically analyzed using SPSS software (Statistical Package for the Social Sciences, version 16, SPSS Inc. Chicago, IL, USA). For quantitative data,

\section{Results:}

Table (1): Demographic characteristics of the study Academic staff in Mansoura faculty of nursing $(\mathrm{n}=118)$.

\begin{tabular}{|l|c|c|}
\hline \multicolumn{1}{|c|}{ Variables } & The study academic staff (n=118) \\
\cline { 2 - 3 } & n & \% \\
\hline -Age (years): & 13 & 11.0 \\
$<25$ & 51 & 43.2 \\
$25-<30$ & 23 & 19.5 \\
$30-34$ & 31 & 26.3 \\
$>34$ & & \\
-Department: & 18 & 15.3 \\
Nursing Administration & 15 & 12.7 \\
Geriatric Nursing & 13 & 11.0 \\
Community Health Nursing & 13 & 11.0 \\
Psychiatric Nursing & 14 & 11.9 \\
Gerontology and Midwifery of Nursing & 15 & 12.7 \\
Critical Care Nursing & 17 & 14.4 \\
Medical surgical Nursing & 13 & 11.0 \\
Pediatric Nursing & & \\
-Marital status: & 103 & 87.3 \\
Married & 15 & 12.7 \\
Unmarried & & \\
-Qualification: & 33 & 28.0 \\
Demonstrator & 18 & 15.3 \\
Assistant lecturer & 63 & 53.4 \\
Lecturer & 4 & 3.4 \\
Assistant professor & 71 & 60.2 \\
\hline Experience years: & 20 & 16.9 \\
1-<5 & 20 & 5.9 \\
5-<10 & 7 & \\
10-14 & & \\
>14 & & \\
\hline
\end{tabular}

Table (1) shows demographic characteristics of the studied sample. The majority of the studied sample aged from 25-30 years old (43.2\%). The highly percent of participation of the studied sample was from Nursing Administration department $(15.3 \%)$. The majority of the studied sample were married $(87.3 \%)$ also the most of them were lecturers $(53.4 \%)$ and have from one to less than five years of experience $(60.2 \%)$. the range, mean and standard deviation were calculated. For qualitative data, comparison between two groups and more was done using Chi-square test $\left(\chi^{2}\right)$. Correlation between variables was evaluated using Pearson's correlation coefficient (r). Significance was adopted at $\mathrm{p}<0.05$ for interpretation of results of tests of significance (18). 
Table (2): Self-esteem of the study Academic staff in Mansoura faculty of nursing ( $\mathrm{n}=118$ ).

\begin{tabular}{|l|c|c|}
\hline \multicolumn{1}{|c|}{ Self-esteem } & The study academic staff (n=118) \\
\% \\
\hline -Level of Self-esteem: & 27 & 22.9 \\
Low (21-27) & 83 & 70.3 \\
Moderate (28-34) & 8 & 6.8 \\
High (35-42) & \multicolumn{2}{|c|}{$24-39$} \\
\hline -Scores of self-esteem: & \multicolumn{2}{|c|}{$29.93 \pm 3.06$} \\
Range (21-42) & \multicolumn{2}{|c|}{} \\
Mean \pm SD & \multicolumn{2}{|c|}{} \\
\hline
\end{tabular}

Table (2) represents the level of self esteem of the studied sample. The most of the studied sample had moderately self esteem (70.3\%) while the least had high self esteem (6.8\%).

Table (3): Emotional intelligence of the academic nursing staff in Mansoura faculty of nursing $(\mathrm{n}=118)$.

\begin{tabular}{|c|c|c|c|c|c|c|}
\hline \multirow{3}{*}{$\begin{array}{l}\text { Emotional intelligence sub- } \\
\text { items }\end{array}$} & \multicolumn{6}{|c|}{$\begin{array}{l}\text { Level of emotional intelligence of the study } \\
\text { academic staff }(n=118)\end{array}$} \\
\hline & \multirow{2}{*}{$\frac{\text { Low }}{\mathbf{N}}$} & \multicolumn{2}{|c|}{ Moderate } & \multicolumn{3}{|l|}{ High } \\
\hline & & $\%$ & $\mathbf{n}$ & $\%$ & n & $\%$ \\
\hline \multirow{2}{*}{$\begin{array}{l}\text { 1-Self consciousness } \\
\text { Range }(8-40) \\
\text { Mean } \pm S D\end{array}$} & 0 & 0 & 6 & 5.1 & 112 & 94.9 \\
\hline & \multicolumn{6}{|c|}{$\begin{array}{c}25-40 \\
34.58 \pm 3.68\end{array}$} \\
\hline \multirow{2}{*}{$\begin{array}{l}\text { 2-Self regulation } \\
\text { Range }(8-40) \\
\text { Mean } \pm S D\end{array}$} & 4 & 3.4 & 38 & 32.2 & 76 & 64.4 \\
\hline & \multicolumn{6}{|c|}{$\begin{array}{c}16-40 \\
30.12 \pm 5.21\end{array}$} \\
\hline \multirow{2}{*}{$\begin{array}{l}\text { 3-Motivation } \\
\text { Range }(8-40) \\
\text { Mean } \pm \text { SD }\end{array}$} & 0 & 0 & 32 & 27.1 & 86 & 72.9 \\
\hline & \multicolumn{6}{|c|}{$\begin{array}{c}23-40 \\
32.61 \pm 4.37\end{array}$} \\
\hline \multirow{2}{*}{$\begin{array}{l}\text { 4-Empathy } \\
\text { Range (6-30) } \\
\text { Mean } \pm \text { SD }\end{array}$} & 0 & 0 & 11 & 9.3 & 107 & 90.7 \\
\hline & \multicolumn{6}{|c|}{$\begin{array}{c}15-30 \\
24.82 \pm 3.18\end{array}$} \\
\hline \multirow{2}{*}{$\begin{array}{l}\text { 5-Social skill } \\
\text { Range (7-35) } \\
\text { Mean } \pm \text { SD } \\
\end{array}$} & 0 & 0 & 37 & 31.4 & 81 & 68.6 \\
\hline & \multicolumn{6}{|c|}{$\begin{array}{c}20-35 \\
28.39 \pm 3.59\end{array}$} \\
\hline \multirow{2}{*}{$\begin{array}{l}\text { Total emotional intelligence: } \\
\text { Range (37-185) } \\
\text { Mean } \pm \text { SD }\end{array}$} & 0 & 0 & 18 & 15.3 & 100 & 84.7 \\
\hline & \multicolumn{6}{|c|}{$\begin{array}{c}117-185 \\
150.52 \pm 15.13\end{array}$} \\
\hline
\end{tabular}

Table (3) shows the level of emotional intelligence of academic staff. According to this table, the academic staff were highly self consciousness (94.9\%) followed by Empathy $(90.7 \%)$ while self regulation has the lowest percent $(64.9 \%)$ from emotional intelligence sub items. 
Table (4): Conflict management practice of the study academic staff in Mansoura faculty of nursing $(n=118)$.

\begin{tabular}{|l|c|c|}
\hline \multirow{2}{*}{ Conflict management practice } & \multicolumn{2}{|c|}{ The study academic staff } \\
& \multicolumn{1}{|c|}{ N } & $\%$ \\
\cline { 2 - 3 } & & 0 \\
-Level of conflict management: & 0 & 23.7 \\
Low (25-66) & 28 & 76.3 \\
Moderate (67-108) & 90 & \\
High (109-150) & \multicolumn{2}{|}{} \\
\hline -Scores of conflict management: & $78-148$ \\
Range (25-150) & $117.30 \pm 12.31$ \\
Mean \pm SD & & \\
\hline
\end{tabular}

Table (4) represents the conflict management practice of the studied sample. This table shows that the most academic staff had high level of conflict management practice $(76.3 \%)$ and only (23.7\%) had moderate level and no one had low level.

Table (5): Relationship between self-esteem and conflict management practice of the study academic staff in Mansoura faculty of nursing $(n=118)$.

\begin{tabular}{|c|c|c|c|c|c|c|c|c|}
\hline \multirow{3}{*}{ Conflict management practice } & \multicolumn{8}{|c|}{$\begin{array}{l}\text { Level of self-esteem of the study academic staff } \\
\qquad(n=118)\end{array}$} \\
\hline & \multicolumn{2}{|c|}{$\begin{array}{c}\text { Low } \\
(\mathbf{n}=27)\end{array}$} & \multicolumn{2}{|c|}{$\begin{array}{l}\text { Moderate } \\
(\mathbf{n}=\mathbf{8 3})\end{array}$} & \multicolumn{2}{|c|}{$\begin{array}{l}\text { High } \\
(\mathrm{n}=8)\end{array}$} & \multicolumn{2}{|c|}{$\begin{array}{c}\text { Total } \\
(n=118)\end{array}$} \\
\hline & $\mathbf{n}$ & $\%$ & $\mathbf{N}$ & $\%$ & $\mathbf{N}$ & $\%$ & n & $\%$ \\
\hline -Level of conflict management: & & & & & & & & \\
\hline Low $(25-66)$ & 0 & 0 & 0 & 0 & 0 & 0 & 0 & 0 \\
\hline Moderate (67-108) & 6 & 22.2 & 21 & 25.3 & 1 & 12.5 & 28 & 23.7 \\
\hline High (109-150) & 21 & 77.8 & 62 & 74.7 & 7 & 87.5 & 90 & 76.3 \\
\hline$\chi^{2}$ & \multicolumn{6}{|c|}{$\begin{array}{l}0.705 \\
0.703\end{array}$} & & \\
\hline $\begin{array}{l}\mathbf{R} \\
\mathbf{P}\end{array}$ & & & & & & & & 327 \\
\hline
\end{tabular}

$r=$ Correlation coefficient

Figure (1): Relationship between self-esteem and conflict management practice of the study academic staff in Mansoura faculty of nursing $(n=118)$.

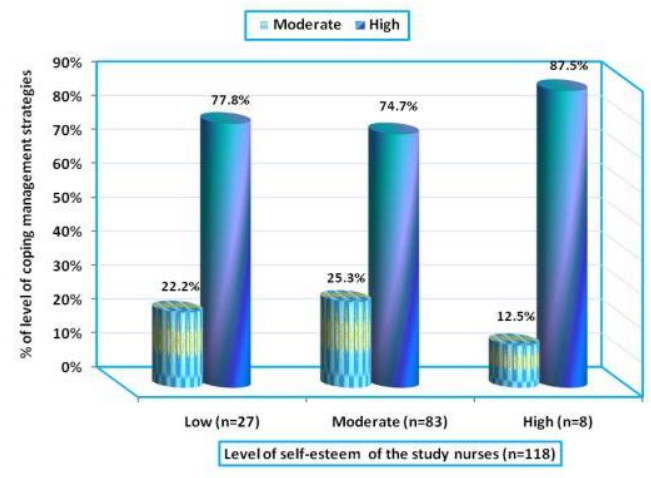


SELF ESTEEM, EMOTIONAL INTELLIGENCE AND CONFLICT etc...

Table (5) and figure (1) illustrate the relationship between self esteem and conflict management practice of the studied sample. There was no significant relationship between academic staff level of self esteem and conflict management practice $(\mathrm{P}=0.703)$.

Table (6): Relationship between emotional intelligence and Conflict management practice of the study academic staff in Mansoura faculty of nursing $(n=118)$.

\begin{tabular}{|c|c|c|c|c|c|c|c|c|}
\hline \multirow{3}{*}{$\begin{array}{l}\text { Level of emotional } \\
\text { intelligence } \\
\text { items }\end{array}$} & \multicolumn{6}{|c|}{$\begin{array}{l}\text { Level of conflict management practice } \\
\text { of the study nursing staff ( } n=118 \text { ) }\end{array}$} & \multirow{3}{*}{$\chi^{2}$} & \multirow{3}{*}{$\mathbf{P}$} \\
\hline & \multicolumn{2}{|c|}{$\begin{array}{l}\text { Moderate } \\
(\mathbf{n}=\mathbf{2 8})\end{array}$} & \multicolumn{2}{|c|}{$\begin{array}{c}\text { High } \\
(\mathbf{n}=90)\end{array}$} & \multicolumn{2}{|c|}{$\begin{array}{c}\text { Total } \\
(n=118)\end{array}$} & & \\
\hline & $\mathbf{n}$ & $\%$ & $\mathbf{N}$ & $\%$ & $\mathbf{N}$ & $\%$ & & \\
\hline 1-Self conscious & & & & & & & & \\
\hline Moderate & 3 & 50.0 & 3 & 50.0 & 6 & 5.1 & 2.411 & 0.121 \\
\hline High & 25 & 22.3 & 87 & 77.7 & 112 & 94.9 & & \\
\hline 2-Self regulation & & & & & & & & \\
\hline Low & 0 & 0 & 4 & 100 & 4 & 3.4 & 17.670 & $0.0001 *$ \\
\hline Moderate & 18 & 47.4 & 20 & 52.6 & 38 & 32.2 & & \\
\hline High & 10 & 13.2 & 66 & 86.8 & 76 & 64.4 & & \\
\hline 3-Motivation & & & & & & & & \\
\hline Moderate & 12 & 37.5 & 20 & 62.5 & 32 & 27.1 & 4.601 & $0.032 *$ \\
\hline High & 16 & 18.6 & 70 & 81.4 & 86 & 72.9 & & \\
\hline 4-Empathy & & & & & & & & \\
\hline Moderate & 5 & 45.5 & 6 & 54.5 & 11 & 9.3 & 3.164 & 0.075 \\
\hline High & 23 & 21.5 & 84 & 78.5 & 107 & 90.7 & & \\
\hline 5-Social skill & & & & & & & & \\
\hline Moderate & 14 & 37.8 & 23 & 62.2 & 37 & 31.4 & 5.929 & $0.015 *$ \\
\hline High & 14 & 17.3 & 67 & 82.7 & 81 & 68.6 & & \\
\hline Total emotional intelligence & & & & & & & & \\
\hline Moderate & 11 & 61.1 & 7 & 38.9 & 18 & 15.3 & 16.400 & $0.0001 *$ \\
\hline High & 17 & 17.0 & 83 & 83.0 & 100 & 84.7 & & \\
\hline $\begin{array}{l}\mathrm{R} \\
\mathrm{P}\end{array}$ & & & & & & & $\begin{array}{c}0.687 \\
0.0001 *\end{array}$ & \\
\hline
\end{tabular}

*Significant $(\mathbf{P}<\mathbf{0 . 0 5})$

$r=$ Correlation coefficient

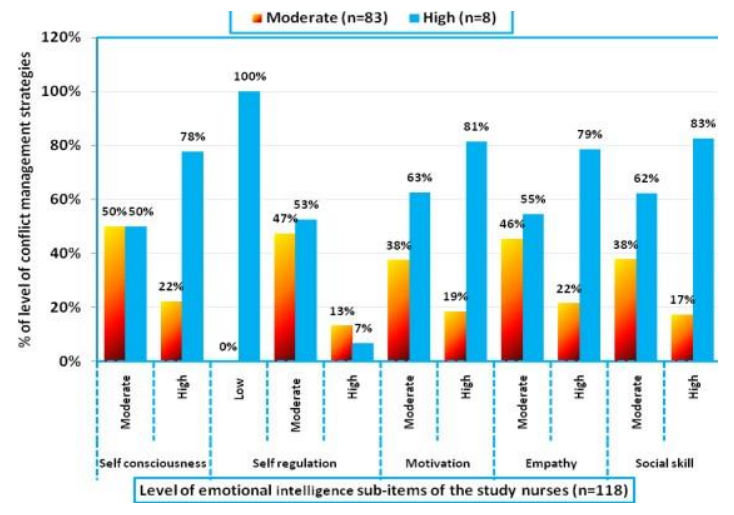


Figure (3): Relationship between total emotional intelligence and conflict management strategies of the study nursing staff in Mansoura faculty of nursing $(n=118)$.

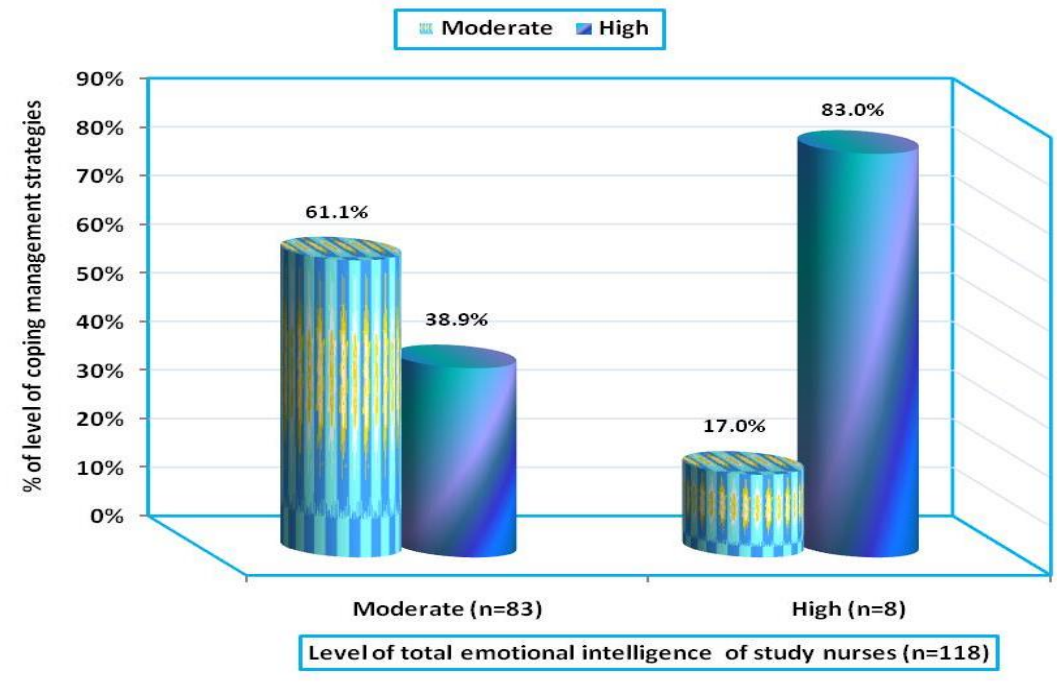

Figure (4): Correlation between total emotional intelligence scores and conflict management strategies scores of the study nursing staff in Mansoura faculty of nursing $(\mathrm{n}=118)$.

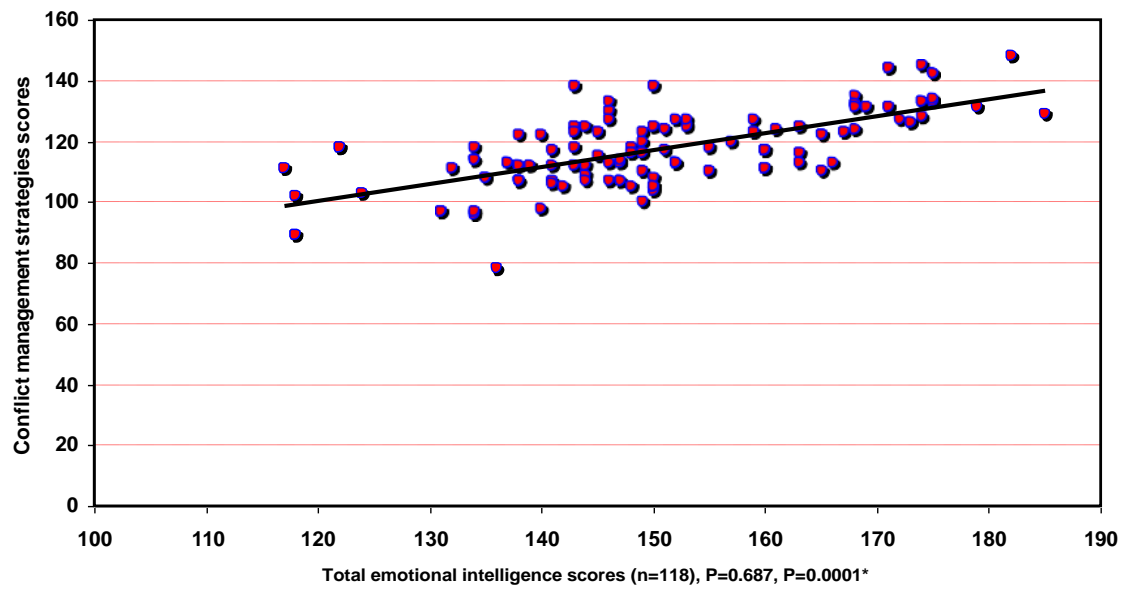

Table (6) and figures (2-4) represents the relationship between sub items and total emotional intelligence and conflict management strategies of the studied sample. There was a highly significant positive relationship between level of total emotional intelligence and its sub items and level of conflict management practice except for self consciousness. Also, there was a significant positive correlation between total scores of both emotional intelligence and conflict management strategies $(\mathrm{P}=0.0001)$. 
SELF ESTEEM, EMOTIONAL INTELLIGENCE AND CONFLICT etc...

Table (7): Relationship between level of self-esteem of the study nursing staff in Mansoura faculty of nursing and their demographic data $(n=118)$.

\begin{tabular}{|c|c|c|c|c|c|c|c|c|c|c|}
\hline \multirow[t]{3}{*}{ Variables } & \multicolumn{8}{|c|}{$\begin{array}{l}\text { Level of self-esteem of the study academic staff } \\
(n=118)\end{array}$} & \multirow[t]{3}{*}{$\chi^{2}$} & \multirow[t]{3}{*}{$\mathbf{P}$} \\
\hline & \multicolumn{2}{|c|}{$\begin{array}{l}\begin{array}{l}\text { Low } \\
(n=27)\end{array} \\
\end{array}$} & \multicolumn{2}{|c|}{$\begin{array}{l}\text { Moderate } \\
(\mathbf{n}=\mathbf{8 3})\end{array}$} & \multicolumn{2}{|c|}{$\begin{array}{l}\text { High } \\
(\mathbf{n}=8)\end{array}$} & \multicolumn{2}{|c|}{$\begin{array}{l}\text { Total } \\
(n=118)\end{array}$} & & \\
\hline & $\mathbf{N}$ & $\%$ & $\mathbf{n}$ & $\%$ & $n$ & $\%$ & n & $\%$ & & \\
\hline -Age (years): & & & & & & & & & & \\
\hline$<25$ & 1 & 7.7 & 11 & 84.6 & 1 & 7.7 & 13 & 11.0 & 6.814 & 0.338 \\
\hline $25-<30$ & 10 & 19.6 & 39 & 76.5 & 2 & 3.9 & 51 & 43.2 & & \\
\hline $30-34$ & 8 & 34.8 & 12 & 52.2 & 3 & $\begin{array}{l}13 . \\
0\end{array}$ & 23 & 19.5 & & \\
\hline$>34$ & 8 & 25.8 & 21 & 67.7 & 2 & 6.5 & 31 & 26.3 & & \\
\hline \multicolumn{11}{|l|}{-Department: } \\
\hline Nursing Administration & 5 & 27.8 & 10 & 55.6 & 3 & $\begin{array}{l}16 . \\
7\end{array}$ & 18 & 15.3 & 20.976 & 0.102 \\
\hline Geriatric Nursing & 2 & 13.3 & 13 & 86.7 & 0 & 0 & 15 & 12.7 & & \\
\hline Community Health Nursing & 6 & 46.2 & 7 & 53.8 & 0 & 0 & 13 & 11.0 & & \\
\hline Psychiatric Nursing & 4 & 30.8 & 8 & 61.5 & 1 & 7.7 & 13 & 11.0 & & \\
\hline $\begin{array}{l}\text { Gerontology and midwifery } \\
\text { Nursing }\end{array}$ & 2 & 14.3 & 10 & 71.4 & 2 & $\begin{array}{l}14 . \\
3\end{array}$ & 14 & 11.9 & & \\
\hline Critical Care Nursing & 6 & 40.0 & 9 & 60.0 & 0 & 0 & 15 & 12.7 & & \\
\hline Medical surgical Nursing & 0 & 0 & 16 & 94.1 & 1 & 5.9 & 17 & 14.4 & & \\
\hline Pediatric Nursing & 2 & 15.4 & 10 & 76.9 & 1 & 7.7 & 13 & 11.0 & & \\
\hline \multicolumn{11}{|l|}{-Marital status: } \\
\hline Married & 22 & 21.4 & 73 & 70.9 & 8 & 7.8 & $\begin{array}{l}10 \\
3\end{array}$ & 87.3 & 2.018 & 0.365 \\
\hline Unmarried & 5 & 33.3 & 10 & 66.7 & 0 & 0 & 15 & 12.7 & & \\
\hline \multicolumn{11}{|l|}{-Qualification: } \\
\hline Demonstrator & 7 & 21.2 & 23 & 69.7 & 3 & 9.1 & 33 & 28.0 & 7.350 & 0.290 \\
\hline Assistant lecturer & 7 & 38.9 & 9 & 50.0 & 2 & $\begin{array}{l}11 . \\
1\end{array}$ & 18 & 15.3 & & \\
\hline Lecturer & 11 & 17.5 & 49 & 77.8 & 3 & 4.8 & 63 & 53.4 & & \\
\hline Assistant professor & 2 & 50.0 & 2 & 50.0 & 0 & 0 & 4 & 3.4 & & \\
\hline \multicolumn{11}{|l|}{-Experience years: } \\
\hline $1-<5$ & 10 & 14.1 & 57 & 80.3 & 4 & 5.6 & 71 & 60.2 & 19.261 & $0.004 *$ \\
\hline $5-<10$ & 9 & 45.0 & 9 & 45.0 & 2 & $\begin{array}{l}10 . \\
0\end{array}$ & 20 & 16.9 & & \\
\hline $10-14$ & 5 & 25.0 & 15 & 75.0 & 0 & 0 & 20 & 16.9 & & \\
\hline$>14$ & 3 & 42.9 & 2 & 28.6 & 2 & $\begin{array}{l}28 . \\
6\end{array}$ & 7 & 5.9 & & \\
\hline
\end{tabular}

*Significant $(\mathbf{P}<\mathbf{0 . 0 5})$

Table (7) shows the relationship between level of self esteem and demographic characteristics of studied sample. According to this table there is no significant relationship with demographic characteristics except for a significant relationship between the level of self esteem and their years of experience $(\mathrm{P}=0.004)$. 
Table (8): Relationship between level of emotional intelligence of the study nursing staff in Mansoura faculty of nursing and their demographic data $(n=118)$.

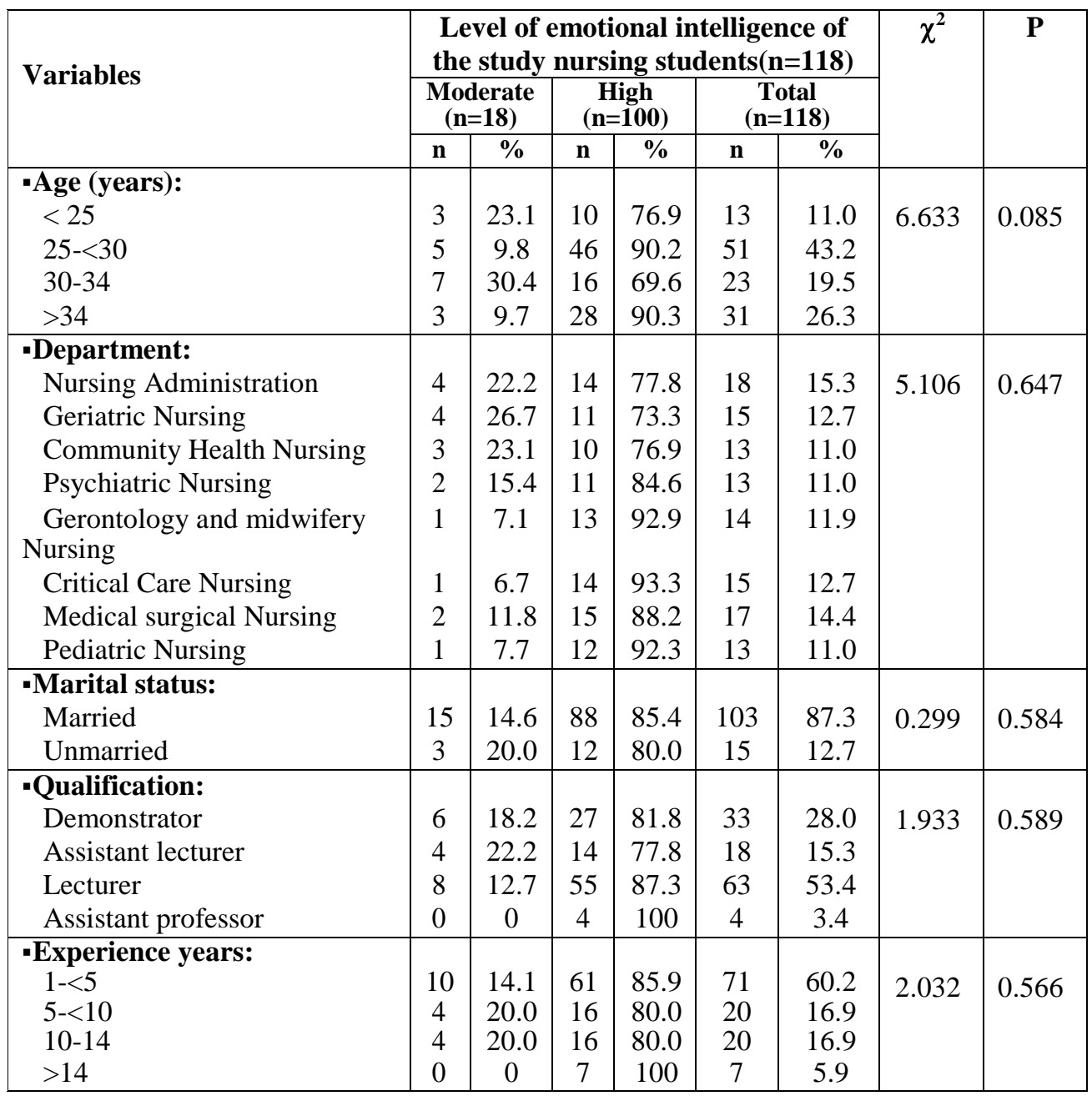

Table (8) shows the relationship between level of emotional intelligence of the studied sample and their demographic characteristics. According to this table, there is no significant relationship between emotional intelligence and demographic characteristics of academic staff. 
Table (9): Relationship between level of coping management strategies of the study nursing staff in Mansoura faculty of nursing and their demographic data $(n=118)$.

\begin{tabular}{|c|c|c|c|c|c|c|c|c|}
\hline \multirow{3}{*}{ Variables } & \multicolumn{6}{|c|}{$\begin{array}{c}\text { Level of conflict management practice } \\
\text { of the academic staff }(n=118)\end{array}$} & \multirow[t]{3}{*}{$\chi^{2}$} & \multirow[t]{3}{*}{$\mathbf{P}$} \\
\hline & \multicolumn{2}{|c|}{$\begin{array}{c}\text { Moderate } \\
(n=18)\end{array}$} & \multicolumn{2}{|c|}{$\begin{array}{c}\text { High } \\
(n=100)\end{array}$} & \multicolumn{2}{|c|}{$\begin{array}{c}\text { Total } \\
(n=118)\end{array}$} & & \\
\hline & $\mathbf{n}$ & $\%$ & $\mathbf{n}$ & $\%$ & $\mathbf{n}$ & $\%$ & & \\
\hline -Age (years): & & & & & & & & \\
\hline$<25$ & 5 & 38.5 & 8 & 61.5 & 13 & 11.0 & 6.796 & 0.079 \\
\hline $25-<30$ & 7 & 13.7 & 44 & 86.3 & 51 & 43.2 & & \\
\hline $30-34$ & 5 & 1.7 & 18 & 78.3 & 23 & 19.5 & & \\
\hline$>34$ & 11 & 35.5 & 20 & 64.5 & 31 & 26.3 & & \\
\hline -Department: & & & & & & & & \\
\hline Nursing Administration & 7 & 38.9 & 11 & 61.1 & 18 & 15.3 & 5.847 & 0.558 \\
\hline Elderly Nursing & 3 & 20.0 & 12 & 80.0 & 15 & 12.7 & & \\
\hline Community Health & 1 & 7.7 & 12 & 92.3 & 13 & 11.0 & & \\
\hline Nursing & & & & & & & & \\
\hline Psychiatric Nursing & 3 & 23.1 & 10 & 76.9 & 13 & 11.0 & & \\
\hline $\begin{array}{l}\text { Gerontology } \\
\text { midwifery Nursing }\end{array}$ & 3 & 21.4 & 11 & 78.6 & 14 & 11.9 & & \\
\hline Critical Care Nursing & 2 & 13.3 & 13 & 86.7 & 15 & 12.7 & & \\
\hline Medical surgical & 5 & 29.4 & 12 & 70.6 & 17 & 14.4 & & \\
\hline Nursing & & & & & & & & \\
\hline Pediatric Nursing & 4 & 30.8 & 9 & 69.2 & 13 & 11.0 & & \\
\hline -Marital status: & & & & & & & & \\
\hline Married & 24 & 23.3 & 79 & 76.7 & 103 & 87.3 & 0.082 & 0.775 \\
\hline Unmarried & 4 & 26.7 & 11 & 73.3 & 15 & 12.7 & & \\
\hline -Qualification: & & & & & & & & \\
\hline Demonstrator & 10 & 30.3 & 23 & 69.7 & 33 & 28.0 & 3.099 & 0.377 \\
\hline Assistant lecturer & 4 & 22.2 & 14 & 77.8 & 18 & 15.3 & & \\
\hline Lecturer & 12 & 19.0 & 51 & 81.0 & 63 & 53.4 & & \\
\hline Assistant professor & 2 & 50.0 & 2 & 50.0 & 4 & 3.4 & & \\
\hline -Experience years: & & & & & & & & \\
\hline $1-<5$ & 15 & 21.1 & 56 & 78.9 & 71 & 60.2 & 0.809 & 0.847 \\
\hline $5-<10$ & 5 & 25.0 & 15 & 75.0 & 20 & 16.9 & 0.00 & 0.041 \\
\hline $10-14$ & 6 & 30.0 & 14 & 70.0 & 20 & 16.9 & & \\
\hline$>14$ & 2 & 28.6 & 5 & 71.4 & 7 & 5.9 & & \\
\hline
\end{tabular}

Table (10) shows the relationship between level of conflict management strategies and academic staff demographic characteristics. There was no significant relationship between level of conflict management practice and academic staff demographic characteristics.

\section{Discussion}

Today, some staff members experience different levels of conflict degree in the workplace on a regular basis. The individual state guarantees it (20). High conflict level may be harmful for staff members at work, they found psychological distress which will result in 
decrease level of productivity. So, managers are required to manage conflict effectively to promote welfare of their employees (21). Effective conflict management requires skills that are emotionally based and skills that reflect self esteem (22). Good management staff members were suffered from stress, lack of enjoyment and justice, heavy workloads from consumers challenging and organizational marketing strategies and cost effectiveness. So, managers cannot eliminate stress, but can minimize stress level through enhancing emotional intelligence skills (23).

The current study findings showed that there was no significant relationship between academic staff level of self esteem and level of conflict management this result means academic staff ability to manage conflict not connected by the levels of self esteem. This result may be related to that there are factors affecting academic staff conflict management as years of experience, work environment, culture of the organizational members rather than self esteem. Also, conflict resulted in work place occur in a regular basis with different forms which provide academic staff with experience in solving conflict based on intelligence level and ability of academic staff in handling and dealing with problems not self esteem level. This result is supported by (24) who revealed that there was no relation between self esteem and conflict management practice.

On the other hand, the results of the present study revealed that there was a highly significant positive relationship between emotional intelligence and level of conflict management practice. This result means improves individual emotional intelligence will improve the abilities of academic staff to manage conflict. This result may be due to that emotional intelligence increase the ability to control feelings and excitements by oneself and others and the relation between them to reasons about them and to solve problems by them which reflected in understanding the reasons of conflict and choose the most appropriate methods for solving and managing conflict.

This result is accorded with $(\mathbf{2 5 , 2 6 )}$ which revealed that emotional intelligence includes the ability to receive emotions and coordinate these emotions to understand the information related to them also manage them which increase the ability to control feelings and excitements by oneself and others. Which in turn increase the relation between the emotional intelligence and the ability to practice conflict management.

In addition to the result of the present study also is supported by the results of the studies of $(\mathbf{2 7 \& 2 8})$ revealed that if people have the exciting capability, they will have an effective role in facing with everyday conflict. That explains the high relation between emotional intelligence and conflict management practices.

The result of the present study showed that most academic staff in faculty of nursing Mansoura University had moderately level of self esteem. This result may be related to the work environment that participates in increasing self esteem for academic staff rather than personal factor. The faculty of Nursing is a new faculty in the university and provide a lot of branches of service (educational, searching and community services). The number of academic staff insufficient to provide all services so, they obliged to do their best, exert more efforts which result in overload. In addition to, all academic staff in different categories has a sense of responsibility to achieve goals, plans, philosophy, mission and vision of the faculty. Also, self esteem of academic staff reflected in achieving the organizational goals and plans so, firstly plans \& objectives are achieved and secondly self esteem is felt. 
SELF ESTEEM, EMOTIONAL INTELLIGENCE AND CONFLICT etc...

This result not supported by the result of (29) who revealed that if people have the higher exciting skills and intelligence, they will have more self esteem.

The result of this study proved that the academic staff in faculty of Nursing, Mansoura University were had a highly level of emotional intelligence. This result may be related to academic staff working experience. According to their demographic characteristics most of them had haired the faculty less than 5 years, which proved that their emotional intelligence would not be affected by the work nature.

This result is supported by (30) who proved that the emotional intelligence of the staff in the property management industry not affected by job nature. Also, all of them joined the industry from different building so, there is a difference in the demand of their customer which cannot be reflected on their emotional intelligence.

The result of the study revealed that academic staff at Faculty of Nursing, Mansoura University had high level of conflict management practice. This result may be related to the nature of conflict in work place that may occur continuously which provide academic staff with different levels of experience in dealing with conflict whatever their self esteem levels and emotional intelligence abilities. This result is supported by (31) who proved that Head nurses at Mansoura university Hospital had a highly level of conflict management.

The present findings revealed that there was no significant relationship between conflict management practice and academic staff demographic characteristics. This finding agreed with (32) who reported that there is no significant relationship between the preference of conflict management practice and the age and educational levels of the vice presidents of Technical
Institutes in the State of Georgia. And also, with (33) who revealed that no significant relation was found in using conflict management practice in relation to age, qualifications and years of experience. While this findings contradicted with (34) who found that there was a significant association between demographic characteristics and the conflict management choices.

The present findings revealed that there was no significant relationship between emotional intelligence and demographic characteristics of academic staff which means that emotional intelligence not connected with personal age, qualification and other demographic characteristics but it is mainly connected with personality. This finding contradicted with (35) who reported that differences in emotional intelligence and subscales were discovered among various demographic groups such as age groups, gender and marital status. This finding also disagreed with (36) who found differences on emotional intelligence based on demographic variables as single and married subjects differ on how they handle relationships as well as their level of awareness of other's feelings, needs and concerns.

There is a significant relationship between levels of self esteem and years of experience and staff that had more than fourteen years experience had high self esteem. It could be related to that the old staff who had more years experience, had more knowledge, more commitment and were more familiar with work environment that enable them to deal effectively with different situation which increase their self esteem This finding consistent with (37) who reported that demographics had an influence on the selfesteem of college freshmen students especially their age and graduate levels.

\section{Conclusion}

There is no significant relationship between academic staff self esteem and 
conflict management practice. On the other hand, that is a highly significant positive relationship between emotional intelligence and conflict management practice. Most academic staff in faculty of nursing Mansoura University had moderately level of self esteem. The academic staff in faculty of Nursing, Mansoura University were had a highly level of emotional intelligence.

\section{Recommendation :}

1-Periodical workshops must be made to detect causes of low self esteem and poor emotional intelligence in academic staff to make early management of any academic conflicts.

1- Encourage open discussion and effective communication between academic staff and administrative authority so that all academic staff gets the right information at the right time to manage misunderstanding and conflict.

2- Encourage academic staff to participate in putting plans, goals and give them continuous feedback about their performance to increase their level of self esteem.

3- Understanding the feelings and emotions of academic staff from administrative authority of the faculty participated in increasing academic staff emotional intelligence level.

4- Faculty culture participates in forming self esteem level of academic staff rather than personal factors so, it is important to develop and improve faculty culture to improve self esteem level.

\section{Acknowledgements}

First of all thanks to ALLAH who gave me strength to achieve this work. The authors would like to thank the university authorities, participating for their supportive roles in this research.

The authors are grateful to the academic staff who participated in the study. Finally, we feel deeply thankful to our families and colleges in our nursing administration department in addition to faculty members for their help and support in collection of data.

\section{Conflict of interest}

The authors declare that they have no conflict of interests.

\section{Reference:}

1-Olsen, J. M.; Breckler, S. J.; Wiggins, E. C. (2008): Social Psychology

Canadian ed.). Toronto: Thomson Nelson. ISBN 978-017-622452-3.

2-Judge, T. A.; Bono, J. E. (2001) : "Relationship of core selfevaluations traits-self-esteem, generalized self-efficacy, locus of control, and emotional stability-with job satisfaction and job performance: A metaanalysis". Journal of Applied Psychology 86 (1): $\quad 80$ 92. doi:10.1037/0021 9010.86.1 80 . PMID 11302235.

3- Hiadayah Abas, N.,A.(2010): Emotional intelligence and conflict management styles, Published Master Thesis, University of Wisconsin- Stout, Retrieved at November, 2015.

4 Mousavi S., Yarmohammadi S., Nosrat A., and Tarasi Z.(2012) : The Relationship between Emotional Intelligence and Job Satisfaction of Physical Education Teachers. Annals of Biological Research, 3(2): 780 788. Retrieved at November, 2015 from: http://www.Scholarsresearchlibra ry.com.

5- Alfolabi O., Wosola R., and Omole S., (2010) : Influence of Emotional Intelligence and Gender on Job performance and Job Satisfaction among Nigerien 
policemen, Journal of Social Sciences, 2(3):147 -154.

6- Mayer. JD, Salovey P.(1997) : What is emotion intelligence? In

: Salovey P. , Sluyter DJ, editors. Emotional development and emotional intelligence: Educational implications, Newyork, Basic Book, 3-31.

7- Lang, M (2009) : "Conflict management: A gap in business education curricula". Journal of Education For Business 84 (4): 240245. doi: $10.3200 /$ joeb.84.4.2 40-245.

8- Mayer, J.D., Salovey, P., and Caruso, D., R.(2004): A future Consideration of issues of Emotional Intelligence, Psychological Inquiry, 15(3), 249-255.

9. Nurmi, R., W., and Darling,J., R., (1997) : international Management leadership: the primary competitive advantage, International Business press, New York.

10- Borisoff, D., \& Victor, D. A. (1989): Conflict management: A communication skills approach. Englewood Cliffs, NJ: PrenticeHall.

11-Min(2012) in Helaly, S., A.(2013): Emotional Intelligence and Its relation to Nursing Performance among nurses at Mansoura University Hospital and Urology and Nephrology Centre, published Doctorate Thesis, faculty of Nursing, Mansoura University, Pp 3-5.

12-Webster, (2014) : self esteem questionnaire, what is self esteem and stopping your inner critic, webmaster@positiveway.com

13-Goleman, D.(1997) : Emotional intelligence, New York, Washington Press.

14-Greenberg, J. (2008) : "Understanding the vital human quest for self-esteem"
.Perspectives on Psychological

Science 3 (1): 48-

55. doi:10.1111/j.1745 -

6916.2008.00061.x.

15-Hassan zadeh, R,(2007): The motivation and excitement. Tehran : Arasbaran Publication

16-Dawson $B \quad D$ and Trapp $R G$ (2001): Reading the medical literature : Basic \& Clinical Biostatistics. Lange Medical Book/ McGraw - Hill. Medical Publication Division, New York. 3rd ed., Ch. 7-9, PP 161-218 and Ch. 13 , PP 305-314.

17-Keil. J., H. (2000): 'Coaching through Conflict" Dispute Resolution Journal, 55(2), 65-69.

18-Ivshin, E. (2001): 'The study of the meaning of work, emotional intelligence and conflict styles in the work place in the 21 st century " Dissertation abstracts international , 62(02), 1127B.

19-Roman Alzate De saez, (2004): Decision making patterns, conflict styles, and self esteem, 16(1), Pp 110116.

20-Bar-on, R. (2000): The handbook of emotional intelligence, Tossey- Bass, While Company, San Francisco.

21-Syavanchi, J., Forgas, J., and Jam, M.(2001) in Tosang, M., A., Maleki, H., Ahmadimehr, Z., Hariri, M., and Schooshtrai, M.(2013): Relationships between self esteem with Emotional intelligence and marital satisfaction among women, world of science Journal 1(11), 123-130.

22- Khanjani, Zeynab, Ashrafyan, Parvameh, Zeinali, Shirin, Montaze, Negin in Hasanvand,(2012): The relation of Emotional Intelligence with self esteem and Academic progress, international Journal of Psychology and Behavioral Sciences 2(6):231- 236. 
23- Hasanvand, B., and Khaledian, $M$ (2012): the relationship of emotional intelligence with self esteem and academic progress, International Journal of Psychology and behavioral science, 2(6), $231-236$.

24- Mohamed S.,M.(2000) : Head nurses management styles in conflict resolution, Unpublished Master Thesis, faculty of Nursing, Alexandria University.

25- Nabi zadeh Chyane, Ghasim ; Beirami, Mansoor(2010): The relationship of the stress and depression with the academic achievement in successful and failed students. Contemporary psychological quarterly city. Shiraz university learning and training studies Magazine. 1-18, (2) 1

26- Yadalij, Amaloye, Z., Khaledian, M., Kamarzarin, H., Shoshtari, M., and Ahrami, R.(2013) in Tosang, M., A., Maleki, H., Ahmadimehr, Z., Hariri, M., and Schooshtrai, M.(2013): Relationships between self esteem with Emotional intelligence and marital satisfaction among women, world of science Journal 1(11), 123-130.

27- Tamanai far, Mohammedreza, Sedighi Arfai, Faribarzi, Salami Fatemeh, (2010): The relationship of the exciting intelligence, self imaginator and self esteem with the academic achievement. The planning and studying quarterly in higher education, 56, Pp 99-113.

28- Chung-on, Lee (2009): Conflict management styles and emotional intelligence of staff in the property management industry, The HKU scholars Hub, the University of Hong Kong, 5056.

29-Ibrahim, A., A. (2015): Leadership styles and conflict

$\begin{array}{lrr}\text { Management } & \text { strategies of } \\ \text { Headnurses } & \text { at } & \text { Mansoura } \\ \text { University } & & \text { Hospital, } \\ \text { Unpublished Master Thesis, 50. }\end{array}$

30-Antonioni ,D.(1998): Relationship between the big five personality factors and conflict management styles. International journal of conflict management, 9(4): 336-354.

31- Rubin, I. (2008) : The

relationship among emotional intelligence, academic achievement, and demographic characteristics in first-year community college students. Available at: http://gateway.proquest.com/ope nurl?url_ver=Z39.88 -

2004\&res_dat=xri:pqdiss\&rft_va 1_fmt=info:ofi/fmt:kev:mtx:disse rtation\&rft_dat=xri:pqdiss:3318590

32- Pilapil. R., Lazaro. A., and Anne.L. (2015): The Demographic Variables and Emotional Intelligence as Correlates of Work Values: A Cross-Cultural Examination towards Organizational Change. Journal of Economics, Business and Management, 3( 2): 171.

33- Blanchard, M. (2010) : The influence of self esteem and selected demographic characteristic on the academic achievement of freshman students in the colleague of agriculture at a researchextensive university. Published doctorate degree of Philosophy at The School of Human Resource Education and Workforce Development.pp:111.

34-Smith, E. R.; Mackie, D. M. (2007): Social

Psychology (Third ed.). Hove: Psychology Press. ISBN 978-1- 84169408-5. 
SELF ESTEEM, EMOTIONAL INTELLIGENCE AND CONFLICT etc...

35- Tosang, M., A., Maleki, H.,
Ahmadimehr, Z., Hariri, M.,
and Schooshtrai, M.(2013) :
Relationships between self
esteem with $\quad$ Emotional
intelligence and marital
satisfaction among women,
world of science Journal 1(11),
123-130.

36-Virginia. R (1993): A study of the relationship between the preference of conflict management styles, demographics and selected characteristics of vice presidents of Technical Institutes in the State of Georgia. Published doctorate degree of education, faculty of Clark Atlanta University.Pp:51-52. Available at : digitalcommons.auctr.edu/cgi/viewcont ent.cgi?article. 